Reprod. Nutr. Dévelop., 1982, 22 (5), 813-823.

\title{
Short and long-term effects of X-irradiation on ovarian follicular populations in the ewe
}

\author{
M.-A. DRIANCOURT $\left({ }^{*}\right)$, J.-C. MARIANA \\ with the technical assistance of Monique OTTOGALLI and Claudette DION
}

Station de Physiologie de la Reproduction, I.N.R.A., Nouzilly, 37380 Monnaie, France.

\begin{abstract}
Summary. The effects of $X$-irradiation on the total number of follicles larger than $50 \mu \mathrm{m}$ in diameter have been studied 10 and 42 days after treatment (short vs long-term animals). A comparison of short-term and control animals showed a sharp reduction in the healthyfollicle population; only 50 p. 100 of the preantral follicles and 40 p. 100 of the antral follicles survived irradiation. The mitotic index of the antral follicles was also reduced and the between-ovary equilibrium per animal was altered. When compared to short-term animals, long-term ewes did not show follicular compensation similar to that seen after hemicastration. Furthermore, the mitotic index did not increase over the control values. Cyclic ovarian activity was maintained despite this.
\end{abstract}

\section{Introduction.}

Numerous studies have shown that $X$-irradiation decreases reproductive performance in terms of number of fertile animals, number of litters and litter size (rabbit : Regaud and Lacassagne, 1913 ; rat : Ingram, 1958 ; mouse : Peters and Levy, 1964), and that this decrease is linked to a reduction inoocyte number. However, all workers have focussed on the factors of differential follicular sensitivity ; age, species, chromosomal configuration (Mandl, 1964 ; Baker, 1971) or stage of follicular growth (Mandl, 1959) have been shown to influence radiation damage. But, in spite of repeated claims that $\mathrm{X}$-rays destroy all large antral follicles in ewes (Karsch et al., 1970 ; Roche et al., 1974 ; Hansel, 1975), no data are presently available in large domestic animals concerning the follicular populations after $\mathrm{X}$-irradiation. This study was undertaken in adult cycling ewes : 1) to determine if the proportion of destroyed follicles varied according to follicular size ; 2) to study the dynamics of an X-irradiated population and 3) to look for possible follicular compensation in the ovaries after irradiation.

\section{Material and methods.}

Animals. - We used 20 lle-de-France ewes. During the breeding season, on day 13 after synchronized ovulation, all the animals received a prostaglandin $F_{2 \alpha}$

(*) Present address : Animal Research Institute, Werribee, Vic. 3030, Australia. 
injection to induce regression of the corpus luteum, as X-irradiation during the luteal phase often results in its maintenance (Denamur, unpublished data ; Karsch et al., 1970).

The animals were then divided randomly into 3 groups. Four control ewes were laparotomized and kept under halotane inhalation for a period of time equivalent to $\mathrm{X}$-irradiation $(20 \mathrm{~min})$. Eight ewes were exposed to $800-\mathrm{R}$ irradiation; such a dose is known to induce temporary sterility in young women (Baker and Neal, 1977) and to severely reduce the number of primordial and growing follicles in the cow (Erickson, 1967). The other 8 animals were used to study the effect of $2400-R$ irradiation; this dose induced permanent sterility in rabbits (Desaive, 1954) and was higher than the dose used in ewes by Roche et al. (1974) to suppress the large follicles. The ewes were irradiated as follows: Both ovaries were irradiated together using an $X$-ray machine operating at $280 \mathrm{kv}$ and $20 \mathrm{~mA}$; approximately $70 \mathrm{R} / \mathrm{min}$ were delivered over a target distance of $20 \mathrm{~cm}$, using a beam of $8 \mathrm{~cm}$ in diameter. During the period of irradiation, ie $11 \mathrm{~min}$ for the $800-\mathrm{R}$ group and $35 \mathrm{~min}$ for the $2400-\mathrm{R}$ group, the animal was protected by a lead shield 4-mm thick, and the ovaries were kept wet with a physiological saline solution. The treatment effect was then determined at two time intervals. Half of the animals from each group (short-term animals) were castrated 10 days after X-irradiation, while the remainder (long-term animals) were castrated 2 cycles and 10 days after irradiation (43 days after treatment). The experimental animals were thus distributed into five groups: control $(\mathrm{n}=4)$; 800-R short-term ( $\mathrm{n}=4)$; 800-R long-term $(\mathrm{n}=4)$; 2400-R shortterm ( $n=4)$ and $2400-R$ long-term ( $n=4$ ).

Follicular populations. - After ovariectomy, both ovaries were fixed in Bouin-Hollande solution; following embedding, they were cut into $7-\mu \mathrm{m}$ thick serial sections, then mounted and stained with hematoxylin. All the sections of each ovary were inspected under the light microscope and all follicles larger than $5000 \mu \mathrm{m}^{2}$, ie $60 \mu \mathrm{m}$ in diameter or with more than three layers of granulosa cells, were counted; using an image analysis system (ASM Leitz), we determined and computed their area on the section where the nucleolus was found. Follicles were defined as atretic when showing either oocyte damage (follicles with a healthy granulosa layer but an irregularly-shaped oocyte) or the presence of more than five pyknotic bodies on the edge or among the granulosa cells on the section containing the nucleolus. Follicle showing widespread pyknosis and disorganization of the granulosa layer were included in this study ; later types of atresia, in which the granulosa layer was lacking and the antrum was invaded by fibroblasts, were not taken into account.

All the follicles were then distributed into 13 size classes, similar to those described by Cahill, Mariana and Mauléon (1979) and uniformly spaced on a logof-area basis. On the basis of the vicinity relationships found using factorial analysis of correspondance (Lebart and Fénelon, 1971), these 13 classes were further grouped into seven larger ones. Thus, instead of an arbitrary 13-class system, we obtained a much more physiological classification, based on only seven classes. In order to conform to the conventional way of expressing follicular 
size by mean diameter, the follicle was assumed to be circular and an equivalent diameter was calculated and expressed in $\mu \mathrm{m}$.

Mitotic index. - In all the healthy follicles the number of granulosa cells was determined in the section where the oocyte nucleolus was found; this was done by direct counting in follicles smaller than $120 \mu \mathrm{m}$ in diameter, while in larger follicles it was calculated as the product of the area occupied by the granulosa cells and their cellular density measured at five different points in the follicle using a circular graticle.

All cells undergoing mitosis in the same section were then counted. From these data, the proportion of cells in mitosis (mitotic index) was calculated and expressed as a percentage for each follicular class. To show the effects of treatment, a weighted mean and its standard deviation were calculated according to Meier (1953).

Statistical methods. - Due to non-equality of the variances between the experimental groups, analysis was carried out using non-parametric testing (Siegel, 1956). We employed the Mann-Whitney $U$-test to compare the two doses used, the Wilcoxon matched-pairs signed-ranks test to compare the extent of atresia in both the ovaries of each animal, and the Kruskal-Wallis one-way analysis of variance to test the differences in the follicular populations in control, short-term and long-term animals. The differences in mitotic index were detected by analysis of variance after angular transformation of the percentages.

\section{Results.}

Dose effects. - We compared the effect of the two X-ray levels 1800 and $2400 \mathrm{R})$ using the Mann-Whitney U-test. In short-term animals, the follicular population per size class per animal did not change with either dose. In long-term ewes, the only significant difference $(U=1 ; P<0.02)$ was detected in follicles between 80 and $200 \mu \mathrm{m}$ in diameter. Since, with this exception the follicular populations per size class per animal were very similar, the two doses were pooled to study the effects of the treatment.

Effects of $X$-ray treatment on follicular populations per animal. - The number of healthy follicles was significantly reduced $(U=3 ; P<0.02)$ in shortterm animals (mean \pm SEM : $144 \pm 22$ ) compared with the controls $(330 \pm 44)$. A slight, non-significant $(U=16,5 ; P>0.1)$ increase in this number was noticed in long-term ewes (174 \pm 19$)$ when plotted against short-term animals.

Using the Mann-Whitney U-test to compare the number of follicles per class per animal (fig. 1) in control and short-term ewes, we found significant decreases in all size classes in the irradiated ewes; the population of preantral follicles, ie follicles between 50 and $80 \mu \mathrm{m}$ and between 80 and $200 \mu \mathrm{m}$ in diameter, was significantly reduced $(U=5 ; P=0.05$ and $U=4 ; P<0.05$, respectively), as only $54 \mathrm{p}$. 100 of the follicles survived irradiation compared to the controls. A sharper reduction was noticed in the next classes $(200-320,320-500,500-800 \mu \mathrm{m})$ 


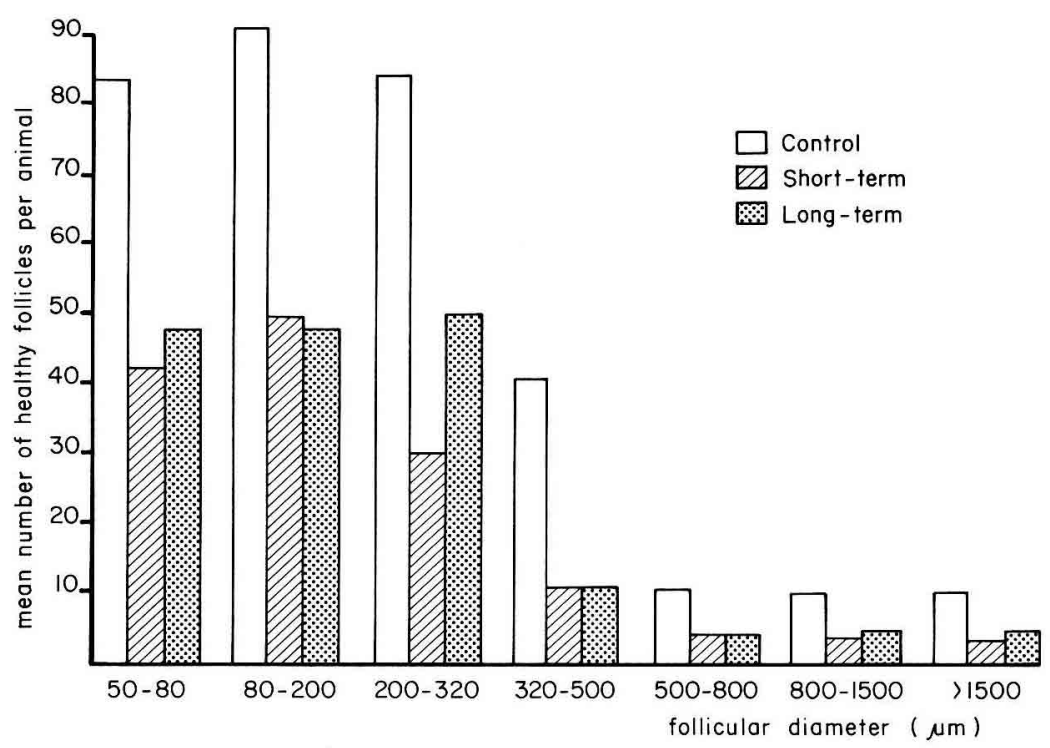

FIG. 1. - The numbers of healthy growin follicles (with an area larger than $5000 \mu \mathrm{m}^{2}$ ) in various follicular size classes per animal in the 3 experimental groups.

which still contained 35 p. $100(U=4 ; P<0.05), 23$ p. $100(U=2 ; P<0.01)$ and 36 p. $100(U=2 ; P<0.01)$ of the follicles compared to the controls. The number of larger antral follicles was also clearly reduced $(U=5 ; P=0.05$ for follicles between 800 and $1500 \mu \mathrm{m}$ and $U=4.5 ; P<0.05$ for follicles larger than $1500 \mu \mathrm{m}$ in diameter), as short-term animals had only 47 and 42 p. 100 respectively, of the population of the untreated ewes in the size classes. Furthermore, to study the largest-follicle population, we compared the diameter of the four largest healthy follicles of each of the control and the short-term animals using the Mann-Whitney U-test. It was found that the largest follicles in the short-term ewes tended to be smaller $(z=1.32 ; 0.05<P<0.1)$ than in the controls.

In a similar study, carried out to compare the individual classes of the follicular populations per animal in short and long-term ewes, we detected a significant difference only in follicles between 200 and $320 \mu \mathrm{m}$ in diameter $(U=3.5 ; P<0.02)$. No increase in any of the other classes of the follicular population occurred in long-term ewes compared to short-term animals. Thus, the population of the long-term group was also between 30 and 50 p. 100 of that of the controls, depending on the size class. The diameter of the largest follicles of the long-term ewes, compared to the controls, was significantly reduced $(z=1.85 ; P<0.05)$, as shown by between-group comparison of the diameter of the four largest healthy follicles of each animal. In contrast, this criterion was not different ( $z=0.08 \mathrm{NS}$ ) in short and long-term groups.

However, it is noteworthy that follicular distribution into size classes was very similar in control, short and long-term ewes, as evidenced by the non-significant value $\left(\chi^{2}=14.8,14 \mathrm{df}\right)$ calculated by the $\chi^{2}$ - test. 
Effect of treatment in mitotic activity. - The relationships between the granulosa mitotic index and follicular size are presented on figure 2 . In control animals, follicular development was characterized by a rapid increase of the proliferative activity of the granulosa in follicles between 320 and $500 \mu \mathrm{m}$ and between 500 and $800 \mu \mathrm{m}$ in diameter, with maximal growth rates in the 800-1 500- $\mu \mathrm{m}$ class. Later on, the mitotic index values dropped.

This pattern of granulosa development was altered in short-term animals. While no significant difference in mitotic index values was noticed in the smaller two classes, the mitotic index of follicles between 200 and $320 \mu \mathrm{m}$ in diameter was significantly increased $(P<0.01)$ compared to the controls. On the contrary, a significant depression of mitotic activity was seen in the 500-800- $\mu \mathrm{m}(\mathrm{P}<0.01$ ), 800-1 500- $\mu \mathrm{m}(\mathrm{P}<0.05)$ and more than $1500-\mu \mathrm{m}(\mathrm{P}<0.01)$ classes.

The mitotic index curve in long-term ewes was similar to that in the controls. In most size classes, the values were quite close, although they were often lower in long-term ewes. However, a significant difference was detected $(P<0.01)$ in follicles between 500 and $800 \mu \mathrm{m}$ in diameter.

Effect of treatment on relative between-ovary distribution of the follicular population per animal. - We compared the follicular population in the right and left ovaries by calculating the ratio between the difference in the population of the two ovaries per animal and the mean population per animal and then plotting it against the follicular diameter (fig. 3). From zero if both ovaries are similar, this ratio will increase to two if one of the two ovaries is completely devoid of follicles.

This ratio was low for preantral follicles in control ewes and then increased in larger antral follicles. However, compared to the controls, significant differences

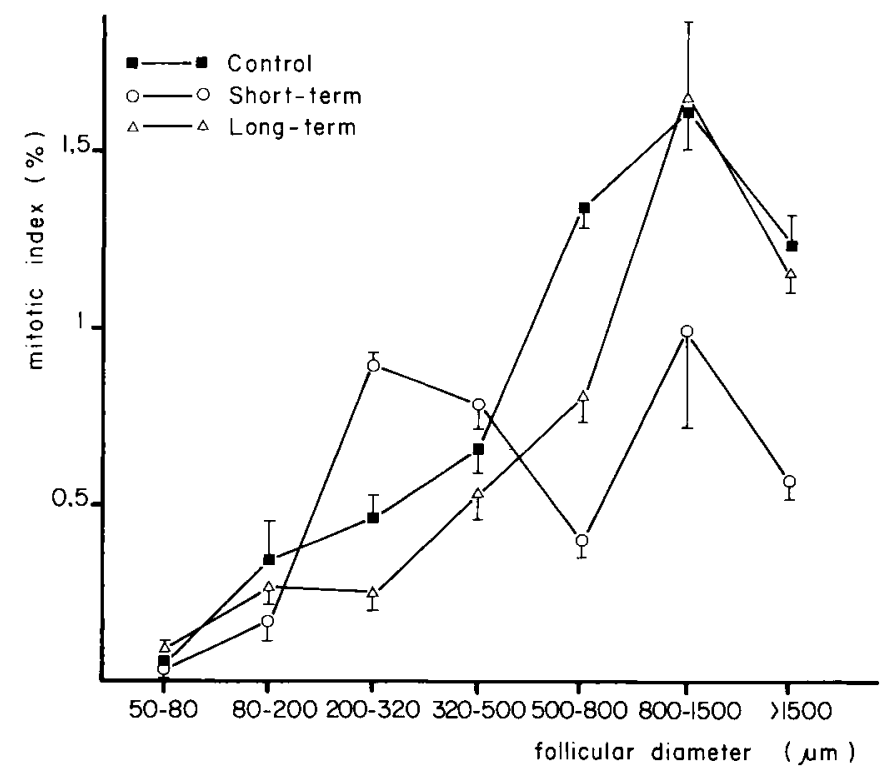

FIG. 2. - The mean mitotic indices of various size classes in short and long-term animals compared to the controls. 


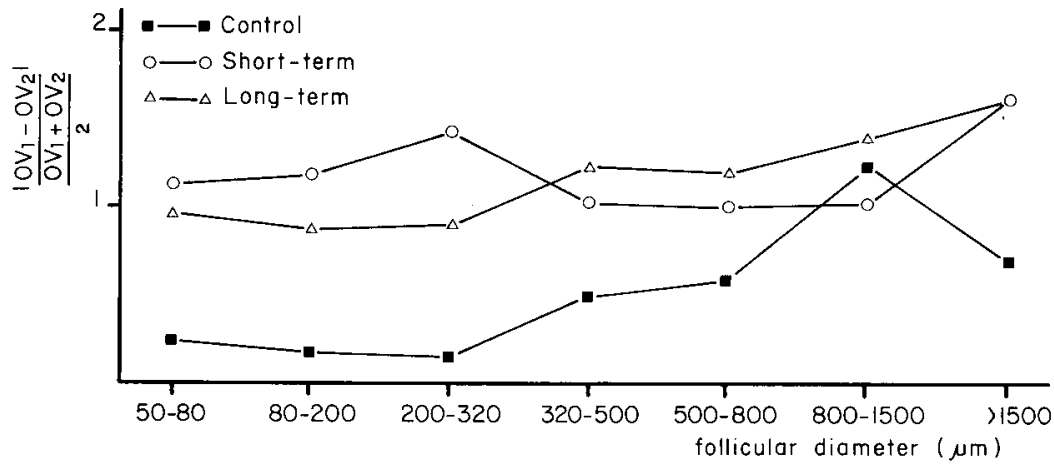

FIG. 3. - The mean population in the various follicular size classes compared in the two ovaries of each animal using the ratio: $\left(\mathrm{OV}_{1}-\mathrm{OV}_{2}\right)$

$$
\frac{O V_{1}+O V_{2}}{2}
$$

were found in the smaller four classes (follicles between 60 and $500 \mu \mathrm{m}$ in diameter) and in the last class (follicles larger than $1500 \mu \mathrm{m}$ ) in short-term as well as long-term ewes. The reasons for the deviation of this ratio are not known.

Effect of treatment on atresia. - Two types of atresia were observed: 1) Follicles with an atretic oocyte and a healthy granulosa layer (photos 1, 2, 3) were found only in long-term animals (mean number : 20 per ovary). Although they occurred irrespective of follicular size, 70 p. 100 were detected in follicles with a diameter of 200 to $500 \mu \mathrm{m}$. In contrast, their frequency was only 5 p. 100 in follicles smaller than $200 \mu \mathrm{m}$ and 5 p. 100 in follicles larger than $1000 \mu \mathrm{m}$.

2) Follicles with a pyknotic granulosa layer were also found. No preantral follicle with a pyknotic granulosa layer was found in this study. For the largest follicles (>800 $\mu \mathrm{m}$ in diameter) of each animal, we calculated a percentage of atresia, defined as the ratio between the number of atretic follicles and the total number of healthy plus atretic follicles. The median value of this percentage was 49 p. 100 for the controls, 54 p. 100 for short-term and 40 p. 100 for long-term animals. However, despite the fact that this decrease in atresia was observed in 6 of the 8 long-term ewes, it was not significant $(U=12.5 ; P>0.1)$ (fig. 4). As the follicular population in irradiated animals differed between ovaries, the Wilcoxon test was used to assess the extent of atresia in each ewe; compared to the contralateral ovary, the one having the smallest number of follicles presented the higher percentage of atresia $(T=1 ; \mathrm{P}<0.02)$.

PHOTO 1. - Preantral follicle in à long-term animal. Note the healthy granulosa layer with an atretic, irregularly-shaped occyte. (x 133). PHOTO 2. - Antral follicle in a long-term ovary. Note that the granulosa is not pyknotic but that an atretic oocyte is present. $(\times 83)$. PHOTO 3 . Higher magnification of an atretic oocyte in an healthy-looking gramulosa. ( $\times 515)$. PHOTO 4. Remnants of preantral follicles at the periphery of an irradiated, short-term ovary. $(\times 126)$. PHOTO 5. - Higher magnification pf preantral follicle remnants in a short-term animal. $(\times 460)$. PHOTO 6. - Markedly altered follicle in an X-irradiated short-term ovary. Note the large oocyte in the middle of the degenerated granulosa cells. $(\times 198)$. 


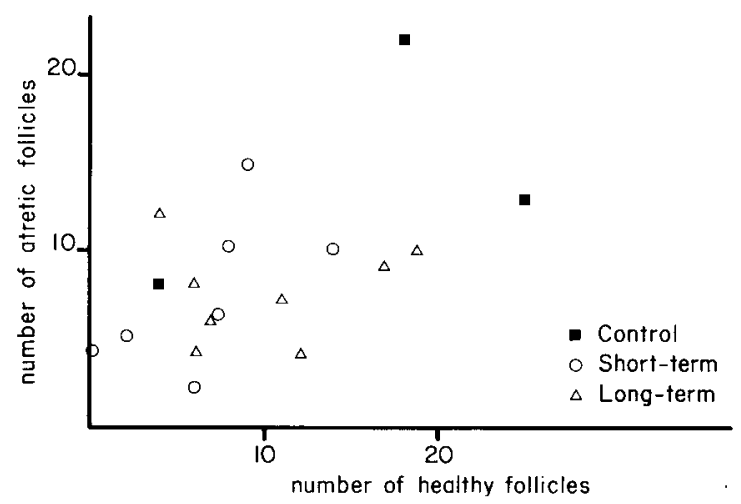

FIG. 4. - Relations between the number of healthy and atretic follicles over $800 \mu \mathrm{m}$ in diameter in the three experimental groups. Each point represents an animal.

\section{Discussion.}

In this study, the effects of X-irradiation have been investigated at two different time intervals (10 and 42 days) after treatment. The short-term animals were slaughtered too late to observe the damaging effect of the $X$-rays as these effects appear soon after irradiation; granulosa cell pyknosis in the Graafian follicles of adult rats, together with a lack of mitotic figures, disorganization of the cumulus oophorus and resumption of meiosis in small follicles (Mandl, 1959), occured as early as $4 \mathrm{~h}$ after irradiation. Furthermore, in mice and rabbits, the primordial follicles disappeared between 2 and 7 days after irradiation (Regaud and Lacassagne, 1913 ; Brambell and Parkes, 1927 ; Desaive, 1954). Ten days after $\mathrm{X}$-irradiation in the present study, we found some remnants of the damaged follicles ; in the preantral follicles, the zona pellucida was enclosed in more or less flattened cavities (photos $4,5,6$ ), while in numerous follicles in very late atresia, the antrum was filled with fibroblasts. Thus, 10 days are enough for an atretic antral follicle to disappear in the ovarian stroma. But some caution must be exercised when assessing this result since the atresia induced by $\mathrm{X}$-rays might differ from that in the control animals (Mandl, 1959).

The reasons why 50 p. 100 of the follicular population (almost uniformly distributed in all the size classes) died after irradiation might be linked to effects within the oocyte or the granulosa cells. However, with the exception of the differences in " quality " related to oogenesis, the reasons for differential oocyte sensitivity within a given size class are not clear. In contrast, X-irradiation is known to induce cell death, cells in $G_{2}$ and $M$ phases being the most sensitive and those in $S$ phase the least sensitive (Sinclair and Morton, 1966; Little, 1968). A possible synchronism between the granulosa cells in a given follicle could explain the differential sensitivity of follicles of the same size.

In fact, the follicles we counted in the short-term ewes were those which survived irradiation. The proportion of such follicles compared to the control population is around $50 \mathrm{p}$. 100. Furthermore, in these survivors, granulosa cell 
kinetics, as assessed by the mitotic index, is modified. This could be related to reproductive delay in the descendants of the cells surviving irradiation; the irradiated cells might move into $G_{2}$ from $S$ and $G_{1}$ phases but be delayed to enter in mitosis, thus inducing a drop in the mitotic index (Little, 1968) as noticed in antral follicles of short-term animals. In the same animals, the increase in the mitotic index, observed in follicles between 200 and $300 \mu \mathrm{m}$ in diameter, might be explained by the semi-synchronous division of cells accumulated in $G_{2}$.

One intriguing fact in short-, as well as in long-, term animals is that the $X$ rays altered the equilibrium between the ovaries. This difference between the ovaries of the same animal is, in our opinion, not due to poor manipulation of the $X$-ray machine because the target distance was small $(20 \mathrm{~cm})$, the diameter of the beam wide $(8 \mathrm{~cm})$ and all irradiated animals presented this deviation, while the control ovaries were roughly similar in this and other studies (Cahill et al., 1979 ; Kassi Lahlou and Mariana, unpublished). The reason for such a discrepancy is unclear. The radiosensitivity of the right and left ovaries is similar. However, the fact that the ovary having the large follicle at the time of irradiation was less damaged in 11 of the 16 ewes might suggest a radioprotective role of the cestrogens (Rugh and Clugston, 1955).

Thus, $X$-irradiation induced : 1) a change in the ovarian feedback effect since the number of growing and graafian follicles was only 50 p. 100 of that of the controls; and 2) a change of between-ovary relationships, evidenced by an altered ratio between the populations of the two ovaries of each animal. The long-term group was designed to observe the consequences of these modifications on the follicular population.

One must be cautious when comparing the short and long-term groups because seasonal influence during the two cycles was not measured; however, the seasonal effect was probably small since only limited differences in the total follicular population and the follicular population per size class were detected in lle-de-France (Cahill and Mauléon, 1980) and Merino (Turnbull et al., 1979) ewes. $\mathrm{X}$-irradiation and hemicastration both reduce the follicular population by 50 p. 100, but the long-term effect of these treatments on the ovary differ markedly. In hemicastrated ewes, Dufour et al. (1979) found a significant increase in the number of small growing follicles, together with an increase in the number of large antral follicle after a time-lag of 70 days. In contrast, similar compensatory growth did not occur in irradiated ewes; only follicles with a diameter of 200 $320 \mu \mathrm{m}$ increased in number. This was probably due to the stimulation of the mitotic index in this class. It is not clear why there was no compensatory growth. Cahill and Mauléon (1980) have calculated that a follicle needs 78 days to grow from 50 to $120 \mu \mathrm{m}$ in diameter. Thus, the lime-lag (42 days) between irradiation and castration in long-term animals was long enough for any follicular compensation to be seen in follicles 50 to $80 \mu \mathrm{m}$ in diameter. A likely explanation of this fact would be a selective destruction by $X$-rays of the primordial follicles which give rise to the follicular compensation.

Similarly, Dufour et al. (1979) studying preantral as well as antral follicles in hemicastrated ewes, found an increase in the mitotic index and in the number of follicles with at least one mitosis. In the present study, with the exception of 
follicles between 200 and $320 \mu \mathrm{m}$ in diameter, no increase of mitotic index coincident with a decrease of follicular population has been detected. This would mean that the mechanism proposed by Cahill and Mauléon (1980) to ensure the continuum of follicular growth, ie a negative correlation between mitotic index and follicular index per size class, is not valid for irradiated ewes.

It is impossible to compare ovine ovarian sensitivity to $X$-rays with that of rats (Mandl, 1959) mice (Murray, 1931), guinea-pigs (Genther, 1931) or monkeys (Baker, 1966), as the primordial follicles have not been counted. But no clear-cut differential differential sensitivity between different sized follicles has been shown in the growing-follicle population. This is contrary to the rabbit (Lacassagne and Gricouroff, 1941) where "medium-sized " follicles appeared to be very radioresistant compared to Graafian follicles.

It is noteworthy that cyclic ovarian activity was maintained in long-term animals whose follicular population was reduced by $50 \mathrm{p} .100$ without evidence of any clear-cut modification of either follicular growth or extent of atresia (Driancourt, Blanc and Mariana, 1982). This situation is very similar to that described by Gougeon (1981) in 40-year old woman.

Reçu en février 1982.

Accepté en avril 1982.

Résumé. Les effets de l'irradiation aux rayons $X$ sur le nombre de follicules de taille supérieure à $50 \mu \mathrm{m}$ de diamètre ont été examinés 10 jours (animaux court terme) et 42 jours (animaux long terme) après le traitement, chez des brebis lle-de-France en saison sexuelle.

La comparaison des court terme aux contrôles met en évidence une réduction marquée de la population de follicules sains : seuls 50 p. 100 des follicules préantraux et 40 p. 100 des follicules à antrum résistent à l'irradiation. De plus, l'index mitotique des follicules à antrum est réduit. Enfin, une altération de l'équilibre des populations entre les deux ovaires a été remarquée.

Les animaux long terme ne présentent pas de croissance folliculaire compensatrice analogue à celle observée après hémicastration, quand on les compare aux animaux court terme. Aucune stimulation de l'index mitotique au-dessus des valeurs des témoins n'a été démontrée. Cependant, l'activité ovarienne cyclique est maintenue.

\section{References}

BAKER T. G., 1966. The sensitivity of oocytes in post-natal rhesus monkeys to X-irradiation. $J$. Reprod. Fert., 12, 183-192.

BAKER T. G., 1971. Comparative aspects of the effects od radiation during oogenesis. Mutation Res., 11, 9-22.

BAKER T. G., NEAL P., 1977. Action of ionizing radiations on the mammalian ovary. In S. ZUCKERMAN, B. WEIR. The Ovary. Acad. Press, London.

BRAMBELL F. W. R., PARKES A. S., 1927. Changes in the ovary of the mouse following exposure to X-rays. Proc. roy. Soc. B, 101, 316-336.

CAHILL L. P., MARIANA J. C., MAULEON P., 1979. Total follicular populations in ewes of high and low ovulation rates. J. Reprod. Fert., 55, 27-36.

CAHILL L. P., MAULEON P., 1980. Influence of season, cycle and breed on follicular growth rates in sheep. J. Reprod. Fert., 58, 321-328. 
DESAIVE P., 1954. Influences du mode d'irradiation, de l'hypophysectomie, des hormones gonadotropes et des radioprotecteurs chimiques sur la réponse de l'ovaire de lapine aux rayons Röntgen. Acta radiol, 41, 545-557.

DRIANCOURT M. A., BLANC M. R., MARIANA J. C., 1982. Ovarian activity and hormonal levels of $X$-irradiated ewes (in preparation).

DUFOUR J. J., CAHILL L. P., MAULÉON P., 1979. Short and long-term effects of hypophysectomy and unilateral ovariectomy on ovarian follicular populations in sheep. J. Reprod. Fert., 57, 301-309.

ERICKSON B. H., 1967. Effect of gamma radiation on the prepuberal bovine ovary. Radiation Res., 31, 441-451.

GENTHER I. T., 1931. Irradiation of the ovaries of guinea pigs and its effect on the œstrous cycle. Am. J. Anat., 48, 99.

GOUGEON A., 1981. Cinétique de la croissance et de l'involution des follicules ovariens pendant le cycle menstruel chez la femme. Doct. Etat, Paris VI.

HANSEL W., 1975. Luteal regression in domestic animals. Ann. Biol. anim. Bioch. Biophys., 15, $147-160$.

INGRAM D. L., 1958. Fertility and oocyte numbers after X-irradiation of the ovary. J. Endocr., 17, 81-90.

KARSCH F. J., NOVEROSKE J. W., ROCHE J. F., NORTHON W. H., NALBANDOV A. V., 1970. Maintenance of ovine corpora lutea in the absence of ovarian follicles. Endocrinology, 87, 1228.

LACASSAGNE A., GRICOUROFF G., 1941. Action des radiations sur les tissus. Masson et Cie, Paris.

LACASSAGNE A., DUPLAN J. F., MARCOVICH H., RAYNAUD A., 1962. The action of ionozing radiations on the mammalian ovary. In $S$. ZUCKERMAN, P. ECKSTEIN, A. M. MANDL. The Ovary. Acad. Press, New York.

LEBART L., FÉNELON J. P., 1971. Statistique et informatique appliquées, Dunod, Paris.

LITTLE J. B., 1968. Cellular effects of ionizing radiations. New Engl. J. Med., 278, 308-315.

MANDL A. M., 1959. A quantitative study of the sensitivity of oocytes to X-irradiation. Proc. roy Soc. B, 150, 53-71.

MANDL A. M., 1964. The radiosensitivity of germ cells. Biol. Rev., 39, 288-371.

MEIER M., 1953. Variance of a weighted mean. Biometrics, 9, 59-62.

MURRAY J. M., 1931. A study of the histological structure of mouse ovaries following exposure to roentgen irradiation. Am. J. Roentgenol. rad. Therapy, 25, 1-45.

PETERS H., LEVY E., 1964. Radiation sensitivity of the mouse ovary w; fertility and oocyte survival. Fert. Steril., 15, 407-418.

REGAUD C., LACASSAGNE A., 1913. Sur les processus de dégénérescence des follicules dans les ovaires rontgenisés de la lapine. C. R. Soc. Biol. Paris, 74, 869-871.

ROCHE J. F., KARSCH F. J., FOSTER D. L., DZIUK P. J., 1974. Serum LH in ewes following sequential removal of ovarian follicles, corpora lutea and stroma. J. Reprod. Fert. 40, 215218.

RUGH R., CLUGSTON H., 1955. Radiosensitivity with respect to the œtrus cycle in the mouse. Radiation Res., 2, 227-235.

SIEGEL S., 1956. Non-parametric statistics for the behavioral sciences. Mc Graw Hill Book Co, New York.

SINCLAIR W. K., MORTON R. A., 1966. X-ray sensitivity during cell generation cycle of cultured chinese hamster cells. Radiation Res., 29, 450-474.

TURNBULL K. E., MATTNER P. E., GEORGE J. M., SCARAMUZZI R. J., 1978. The relation between patterns of ovarian follicular growth and ovulation rate in sheep. Aust. J. biol. Sci., 31, 649-655. 